The Egyptian Journal of Biochemistry \& Molecular Biology VOL 35 (N.1\&2)27-40 December. 2017

\title{
SERUM IL17 AND IL4R rs1805010 GENOTYPES: RELATIONSHIP WITH RHEUMATOID ARTHRITIS DISEASE ACTIVITY IN EGYPTIAN PATIENTS
}

\author{
INAS A. AHMED1,2*, BASANT M. ELNADY3, GHADA \\ ALFAYOMI4, MARWA Y. MAHGOUB \\ 1Departments of Medical Biochemistry, 2Molecular Biology \\ unit, 3Rheumatology, Rehabilitation and Physical Medicine, \\ Faculty of Medicine, Benha University, Egypt. 4Department \\ of Rheumatology, Rehabilitation and Physical Medicine, \\ Faculty of Medicine, Mansoura University, Egypt.
}

Received 14/1/2016- Accepted 22/1/2017

\begin{abstract}
Rheumatoid arthritis(RA) is characterized by the presence of a relative state of imbalance between pro- and anti-inflammatory cytokines such as Interleukin(IL)17 and IL4, respectively. IL4 is supposed to regulate production of IL17 from T-helper (Th)17 cells. However, this regulatory function might be affected by singlenucleotide polymorphism (SNP) of IL4 receptor (IL4R) gene, rs1805010. The current study aimed to assess serum IL17 level in Egyptian patients with RA according toIL4Rrs1805010 genotypes, and to detect possibleassociations betweenIL17/ IL4R genotypesand clinical status, disease activity as well as effect of treatment. Serum IL17 was assessed by ELISA, and qPCR was used to determine the genotypes of IL4R SNP rs1805010. Serum IL17 was significantly increased in patients' samples as compared to controls. According to IL4R genotypes, patients with $\mathrm{AG}$ and GG genotypes showed significantly higher IL17 levels than control subjects with corresponding genotypes. Within RA group, significantly higher IL17 were found in GG carriers compared to those with AA genotype. The $\mathrm{G}$ allele was significantly associated with higherythrocyte sedimentation rate(ESR), increased disease activity score in 28 joints
\end{abstract}

* Correspondence Author (e-mail address: inas.ahmed@fmed.bu.edu.eg) 
(DAS28), highLarsen score and seropositive rheumatoid factor (RF) as well as C-reactive protein (CRP).Patients with AG and GG genotypes demonstrated significant positive correlations between serum IL17 and DAS28. Meanwhile, serum IL17 levels and Larsen score had significant positive correlation only in GG patients. The use of different treatment regimens did not affect serum IL17 levels significantly in various genotypes. In conclusion, IL17 may be implicated in the pathogenesis of RA, being associated with a higher disease activity parameters, however, its action may be potentiated due to loss of the functional ILARA allele (rs1805010), particularly in carriers ofthe GG genotype. Furthermore, determining the genetic variants of ILAR rs1805010 may be promising for identification of patients at risk worse prognosis.

Key words:Autoimmune disease; pro-inflammatory cytokines; IL $4 R$ genotypes.

\section{INTRODUCTION}

Rheumatoid arthritis is a systemic inflammatory disorder of chronic nature, associated with destructive synovitis, progressive cartilage and bone damage. The wide prevalence of RA, about $0.5-1 \%$ of the population worldwide, stratifies it as one of the most common autoimmune diseases. Though its exact etiology is still unknown,knowledge related to its pathogenesis is expanding and currently is thought to be driven by complex interactions of cells, like $\mathrm{T}$ cells, macrophages and fibroblasts(Kugyelka et al., 2016).

Previously, CD4+ lymphocytes were thought to comprise two discrete effector cells, the Th1 and Th2 subsets which are responsible for secretion of either interferon (IFN)- $\gamma$ or IL4, respectively. In 2005, a third $\mathrm{T}$ helper cell subset,producing IL-17, was reported and called Th17 cells(Harrington et al., 2005 and Park et al., 2005).Before Th17subset was discovered, IL-17 was suggested to originate from Th1 cells, however, IL-12 was found to inducetransformation ofhuman Th17 cells into Th1 cells (Boniface et al., 2010).

Former studies detected Th17 cells close to osteoclasts in joints of RA patients. They also suggested thatIL17promotes osteoclast differentiation, hence aggravates joint destruction and bone resorption during RA. In addition, local and systemic production of IL17 was detected during initiation of RA in animal models. (Kugyelka et al., 2016). Interestingly, in vitro studies suggested that IFN- $\gamma$ and IL4, 
produced by other Th cell subsets, can suppress Th17 cell development anddownregulateIL17 production(Astry et al., 2011 and Cooney et al., 2011).

The role of IL4 in counteracting RA inflammation is affected by functional SNPs in ILAR(Prots et al., 2006). Replacementof isoleucine (I) byvaline (V) in amino acid chain of IL4R is controlled by SNP(rs1805010) in IL4Rcoding region. Accordingly, the function ofIL4R is modulated (Wallis et al., 2011).

Understanding the interaction between genetic and other molecular markers, such as IL4R rs 1805010 and IL17, may represent a powerful tool for predicting diagnosis, prognosis, improving the treatment strategies, and achieving better outcome of RA disease (Krabben et al., 2013 and Wallis et al., 2011).From this point, the current study aimed to explore the differences in serum IL17 levels according to IL4R genotypes (rs1805010) in Egyptian patients with established RA. Furthermore, toelucidate theirpossible association with RAclinical manifestations and treatment effect.

\section{MATERIALS \& METHODS}

The current study included 170 RA patients who were diagnosed according to 2010 American College of Rheumatology/European League Against Rheumatism (ACR/EULAR) classification criteria(Aletaha et al., 2010). They were selected during regular follow-up at the outpatients' clinic and the inpatients' unit of the Rheumatology and Rehabilitation Department, Benha University Hospitals. Additional 133, age and sex matched, apparently healthy volunteers were recruited as a control group.We excluded patients who were less than 18 years old and thosepresented with overlap or association with any other rheumatic or autoimmune diseasese.gosteoarthritis, psoriatic and lupus arthritis. Control subjects with seropositive RF, CRP, ESR oranti-cyclic citrullinated peptide antibody(Anti-CCP) results were also excluded.The study scheme was approved by the ethical committee of Faculty of Medicine, Benha University andinformed consents were obtained from all participantsbefore enrollment.

Upon enrollment, all patients were subjected to full history taking, complete physical examination, visual analogue scale (VAS) and disease activity assessmentusing the Disease Activity Score in 28 joints (DAS28)(Aletaha et al., 2005). Plain radiographs were obtained 
and the Larsen Grading Scale(Larsen 1995) was used to determine the extent of radiographic changes progression due toRA. The scale scored the extent of joint space narrowing, bony outlines, and degree of erosions. A mean score was calculated separately for the hands, wrists, and feet. The scores of all 32 areas wasaveraged together.

Blood sampling:venous blood was withdrawn from each subject, separated into two parts: the first part was collected into EDTA vacutainers to be used for erythrocyte sedimentation rate assay (Westergreen method) and genotyping assay of ILAR at SNP rs1805010. The secondpart was used to separate serum forRheumatoid Factor(Dorner et al., 1987), C-reactive protein (Dixon et al., 1984), anti-cyclic citrullinated peptide antibody (van Gaalen et al., 2005) assays and the remaining serum was stored at $-20^{\circ} \mathrm{C}$ for later assessment of IL17 level.

Assessment IL17 level: was performed by Infinite F50 absorbance reader (Tecan, Austria) using commercial ELISA assays (Biosource, Camarillo, USA) according to the manufacturer's instructions(Conti et al., 2012)

ILAR Genotyping: whole blood samples were used for DNA extraction using the QIAamp DNA Blood Mini Kit (Qiagen, Germany) following the manufacturer's protocol. DNA concentration was determined using Nanodrop 2000c spectrophotometer (Thermo Scientific, USA). Genotyping of $I L 4 R, \quad r s 1805010$ was performed using TaqMan® Predesigned SNP Genotyping Assay (Applied Biosystems, USA) and TaqMan Universal PCR Master Mix, No AmpErase UNG (Applied Biosystems, USA) according to the manufacturer's instructions.Genotyping assays were performed and analyzed by StepOne real time PCR system (Applied Biosystems, USA).

Statistical analysis: data were summarized in terms of mean \pm SD for quantitative data and frequencies and percentages for qualitative data. Comparisons between the different studied groups were carried out using the Chi-square test $\left(\chi^{2}\right)$, Fisher's Exact Test (FET) and the test of proportion $(\mathrm{Z})$ to compare proportions as appropriate. The Student $\mathrm{t}$-test ( $\mathrm{t}$ ) and Mann-Whiteny test $(\mathrm{z})$ were used to detect differences between two normally and non-normally distributed variables respectively, while the ANOVA (F) and Kruskal Wallis test $\left(\chi^{2}\right)$ were used to compare more than two quantitative data. Genotype frequencies in RA cases and controls were tested for Hardy-Weinberg equilibrium, and significanceof any deviation between the observed and expected frequencies was tested using Chi- square test. 
A p-value $<0.05$ was considered statistically significant. The statistical analysis was conducted using STATA version 11.2 (STATA corporation, College Station, Texas).

\section{RESULTS}

The current study included 170 RA patients (147 females, $86.47 \%$ and 23 males, $13.53 \%$ ). Their ages ranged between 30 and 58 years with a mean of $41.49 \pm 5.57$ years. Other clinical, laboratory and radiologic characteristics of the study groups are shown in table (1)

Table (1): Baseline characteristics of the study groups

\begin{tabular}{|c|c|c|c|}
\hline Parameter & & $\begin{array}{c}\text { RA patients } \\
(\mathbf{n}=170)\end{array}$ & $\begin{array}{c}\text { Controls } \\
(n=133)\end{array}$ \\
\hline Disease duration (years) & \multirow{7}{*}{ 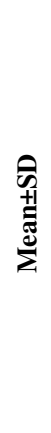 } & $3.14 \pm 2.35$ & NA \\
\hline $\begin{array}{c}\text { Duration of morning stiffness } \\
\text { (minutes) }\end{array}$ & & $66.56 \pm 48.82$ & NA \\
\hline Tender joint count & & $4.52 \pm 3.39$ & NA \\
\hline Swollen joint count & & $3.85 \pm 2.71$ & NA \\
\hline VAS & & $5.82 \pm 9.3$ & $\mathbf{N A}$ \\
\hline DAS28(disease activity) & & $4.27 \pm 1.16$ & NA \\
\hline ESR (mm/1 st $\left.^{\text {hour}}\right)$ & & $49.25 \pm 22.07$ & $11.14 \pm 4.15$ \\
\hline RF positive (\%) & \multirow{4}{*}{$\underbrace{e}_{a}$} & $154(90.59 \%)$ & $0(0 \%)$ \\
\hline CRP positive (\%) & & $129(75.88 \%)$ & $0(0 \%)$ \\
\hline anti-CCP positive (\%) & & $144(84.70 \%)$ & $0(0 \%)$ \\
\hline $\begin{array}{l}\text { Larsen scale } \\
\text { Grade } 1(\%) \\
\text { Grade } 2(\%) \\
\text { Grade } 3(\%) \\
\text { Grade } 5(\%)\end{array}$ & & $\begin{array}{c}63(37.06 \%) \\
89(52.35 \%) \\
16(9.41 \%) \\
2(1.18 \%) \\
\end{array}$ & NA \\
\hline
\end{tabular}

n.: number, NA: not applicable, VAS: visual analogue scale, DAS28: Disease Activity Score in 28 joints.

IL4R genotyping (SNP rs1805010) results were in accordance with Hardy-Weinberg equilibrium. There were 90 patients of AG genotype $(52.94 \%)$, while each of the homo-genotypes (AA or GG) was found in 40patients $(23.53 \%$ each). Regarding the control group, the frequencies were $63(47.37 \%), 37(27.82 \%)$ and $33(24.81 \%)$ for the AG, AA and GG genotypes, respectively. Notably, differences in 
genotype frequencydistribution between the controls and RA patients were insignificant $(\mathrm{p}>0.05)$.

Regarding serum level of IL17, sera of RA patients had significantly higher levels as compared to serum samples of the controls $(\mathrm{p}<0.05)$. Based on genotype classification of both studied groups, IL17 was significantly increased only in AG and GG patients compared to healthy subjects with corresponding genotypes. Importantly, within RA patients, those with GG genotype had significantly elevated serum IL 17 levels as compared to AA patients ( $p<0.05)$. Figure (1).

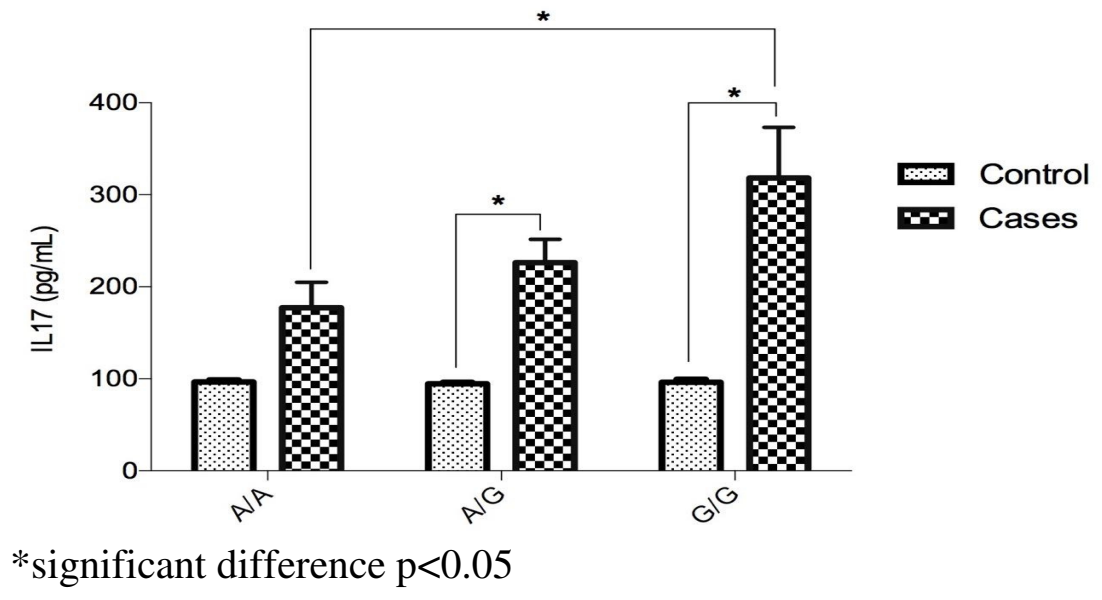

Figure (1): comparison of serum IL17 levels between different genotypes in RA patients and control groups

Within RA patients' group, comparison of various genotypesas regard mean values of DAS28 scale and ESR revealed that they were significant higherin AG patients when compared to those with AA genotype, and in GG patientscompared to AA or AG subgroups, as well (all $\mathrm{p}<0.05$ ).In addition, the current results showed significant differences in frequency distribution of DAS28 grades with GG patients having the highest frequency of the high DAS28 grade $(\mathrm{p}<0.05)$.

Moreover, patients who had GG genotype showed significantly higher frequencies of positive RF and CRP results, as compared to other genotypes.Higher grades of Larsen scale presented with significant association to GG genotype as well $(\mathrm{p}<0.05)$. Table $(2)$. 
Table 2:Association of rs1805010 genotypes with clinical and laboratory features of RA

\begin{tabular}{|c|c|c|c|}
\hline \multirow[b]{2}{*}{ Variable } & \multicolumn{3}{|c|}{ Mean \pm SD } \\
\hline & $\begin{array}{c}\text { Homo A/A } \\
(n=40)\end{array}$ & $\begin{array}{c}\text { Hetero A/G } \\
(\mathbf{n}=90)\end{array}$ & $\begin{array}{c}\text { Homo G/G } \\
(n=40)\end{array}$ \\
\hline \multirow{5}{*}{$\begin{array}{c}\text { DAS28 } \\
\text { Remission }(<2.6) \\
\text { Low }(2.6 \text { to }<3.2) \\
\text { Moderate }(3.2 \text { to5.1) } \\
\text { High }(>5.1)\end{array}$} & $3.28 \pm 1.14$ & $4.30 \pm 0.87 *$ & $5.18 \pm 0.99 * \dagger$ \\
\hline & $21(52.5 \%)$ & $5(5.6 \%)$ & $2(5 \%)$ \\
\hline & $6(15 \%)$ & $17(18.9 \%)$ & $2(5 \%)$ \\
\hline & $10(25 \%)$ & $58(64.4 \%)$ & $7(17.5 \%)$ \\
\hline & $3(7.5 \%)$ & $10(11.1 \%)$ & $29(72.5 \%)$ \\
\hline ESR & 33.5 \pm 17.8 & $48.9 \pm 19.11 *$ & $65.73 \pm 20.7 *$ \\
\hline RF & & & $* * *$ \\
\hline Negative & $9(22.5 \%)$ & $5(5.6 \%)$ & $2(5 \%)$ \\
\hline Positive & $31(77.5 \%)$ & $85(94.4 \%)$ & $38(95 \%)$ \\
\hline CRP & & & $* * *$ \\
\hline Negative & $18(45 \%)$ & $19(21.1 \%)$ & $4(10 \%)$ \\
\hline Positive & $22(55 \%)$ & $71(78.9 \%)$ & $36(90 \%)$ \\
\hline Larsen scale & & & $* * *$ \\
\hline Grade 1 & $5(12.5 \%)$ & $42(46.7 \%)$ & $16(40 \%)$ \\
\hline Grade 2 & $26(65 \%)$ & $41(45.6 \%)$ & $22(55 \%)$ \\
\hline Grade 3 & $9(22.5 \%)$ & $7(7.7 \%)$ & $0(0.0 \%)$ \\
\hline Grade 5 & $0(0.0 \%)$ & $0(0.0 \%)$ & $2(5 \%)$ \\
\hline Anti-CCP & & & \\
\hline Negative & $5(12.5 \%)$ & $15(16.7 \%)$ & $6(15 \%)$ \\
\hline Positive & $35(87.5 \%)$ & $75(83.3 \%)$ & $34(85 \%)$ \\
\hline
\end{tabular}

* Significant differences compared to Homo $\mathrm{A} / \mathrm{A}$; $\uparrow$ significant differences compared to Hetero A/G,

*** significant difference between studied genotypes, $\mathbf{p}<0.05$ : significant In addition, the present study revealed that in patients with $A G, G G$ genotypes, serum IL17 levels were significantly positively correlated to DAS28. However, IL17 serum levels were positively correlated to Larsen scale with significant difference only in patients with GG genotype.Table (3)

Table 3:Correlation coefficient ( $\rho)$ between DAS28, Larsen score and serum IL17 levels in various genotypes of RA patients

\begin{tabular}{|c|c|c|c|}
\hline \multirow{2}{*}{$\approx$} & & DAS28 & Larsen scale \\
\cline { 2 - 4 } & $\mathbf{A} / \mathbf{A}$ & 0.243 & 0.145 \\
\cline { 2 - 4 } & $\mathbf{A} / \mathbf{G}$ & $0.536^{*}$ & 0.089 \\
\cline { 2 - 4 } & $\mathbf{G} / \mathbf{G}$ & $0.439^{*}$ & $0.668^{*}$ \\
\hline
\end{tabular}

$\boldsymbol{\rho}$ : Spearman correlation coefficient (rho), * $\mathbf{p}<0.05$ significant

Finally, RA patients included in this study were using different combination of disease-modifying anti-rheumatic drugs (DMARDs). within each IL4R genotype, the use of different treatment regimen did not affect serum IL17 levels significantly $(p>0.05$ all $)$. 


\section{DISCUSSION}

Previous studies suggested a key role for IL17 in the pathogenesis of RA and pointed to the association between IL4R SNP rs1805010, and RA joint destruction (Krabben et al., 2013). This study was conducted on Egyptian RA patients to assess the differences in serum IL17 levelsbased on genotypes of ILAR SNP rs1805010, and to elucidate their possible association with RA clinical manifestations and treatment effect. To our knowledge, the current work is the first study in Egyptian RA patients to and focus on the relationship between IL4R genotypes and serum IL17, providing more insight on mechanism of action of IL4R with different genotypes.

The role of IL4R genotypes in RA susceptibility in Egyptian patients was previously reported with contradictory results (Hussein et al., 2012 and Mohamed etal., 2015). The present data showed non-significant differencesin genotypes' distribution between RA patients and controls. This result supportsthe previous reports that IL4RSNP (rs1805010) might not be relevant as a risk factor for RA disease(Burgos et al., 2010 and Hussein et al., 2012). However, this observation was in contrast to that of Mohamed etal., 2015. The different samople sizes and use of different technicques for detection of IL4R genotypes may explain such controversy.

Studying clinical activity parameters in different genotypes, results of the current study demonstrated a significant association between rs $1805010 \mathrm{G}$ allele from one side and the higher DAS28, ESR values on the other side. Moreover, patients who had GG genotype presented with significantly higher frequencies of seropositive RF, CRP and higher grades of Larsen scale. In this regard, our results were similar to what was previously reported. After follow up for one year, Leipe and colleagues, 2014 demonstrated that carriers of $G$ variant had significantly higher DAS28 scores than healthy controls.As well, an Egyptian study found that RF seropositivity and bone erosions associated significantly withG allele of ILAR(Hussein et al., 2012). Other reports suggested that carrying $G$ allele was predictive of more severe erosive disease (Leipe et al., 2014 and Prots et al., 2006). Additional evidence was provided by another research group as they stated that moderate DAS scores was found in AG patients while GG patients showed higher scores. They added that though their observation was statistically insignificant, yet it reflects higher disease activity in GG genotype of rs1805010 (Wallis et al., 2011).

However, one study in African American patients with RA, failed to detect any significant association between genotypes of rs 1805010 and RF status, Anti-CCP or radiographic erosions. Such discrepancy may be attributed to different studied races, patients' characteristics and effect of treatment. 
IL4 has been shown to be highly protective cytokine in RA due to its ability to suppress inflammation and joint destruction through many mechanisms. It inhibits production of vascular endothelial growth factor thus possesses antiangiogenic effect, inhibits osteoclastic activity and downregulatestissue metalloproteinase-1 expression and so decreases cartilage destruction(Wallis et al., 2011).Interestingly, binding of IL4 to its receptor activates signal transducer and activator of transcription-6 (STAT6)which upregulates a wide range of genes necessary for Th2differentiation of CD4 T cells.In turn, enhanced differentiation to Th2 cells allows further increase of its product; IL4.(Prots et al., 2006)..

Though ILAR rs1805010 is located near IL4- binding site, prior reports suggested that its effect is mediated through modulating the action of STAT6, rather than changing the affinity for IL4. It has been shown that IL4R-A allele confers protectionin RA patients, through prolonged STAT6 activation, thus increased IL4 production, while the G variant is associated with higher disease activity and rapidly developing erosions due to diminished STAT6 activation and decreased IL4 production (Hussein et al., 2012; Leipe et al., 2014 and Prots et al., 2006) In addition, assessment of serum IL17 revealed significantly higher levels in RApatients compared withcontrol subjects, which is consistent with the results of previous studies in earlyas well as in established RA. They attributed these results to expansion and enhanced activity of Th17 subset in RA patients compared to healthy individuals(Al-Saadany et al., 2016; Edavalath et al., 2016 and Pavlovic et al., 2014)or osteoarthritis patients(Leipe et al., 2010 andWallis et al., 2011).RA was regarded as Th1-driven disease, but this concept has been changed after discovery of Th17 subset and its effector IL17, and currently is thought to be dependent mainly on Th17 cells. Through RA course, complex immune reactions lead to enhanced production ofmany proinflammatory cytokines including IL1 $\beta$ and IL6. Both cytokines have been shown to induce Th17 differentiation and to recruit Th17 to inflammation sites (Kugyelka et al., 2016). A recent in vitro study demonstrated thatactivation of T-cell receptor and direct cell interaction with synoviocytes, were necessary for induction of IL17 secretionby Th17 cells in RA(Noack et al., 2016).

Many mechanisms have been suggested to mediate the pathogenic effects of IL-17 during the progression of RA. At early stages of the disease, IL17 has been shown to stimulate the secretion of vascular endothelial growth factor by synovial fibroblasts, hence, increases neovascularization and angiogenesis. Moreover, IL17 enhances innate immunity through induction of expression of various inflammatory mediators and chemokines including complement system. Additionally, it acts as a chemotactic factor for monocytes and other inflammatory cells facilitating their infiltration into the 
synovial tissues causing arthritis (Astry et al., 2011 and Roeleveld and Koenders 2015)Interestingly, stratification of the study groups according to their ILAR genotypes, demonstrated that the presence of $\mathrm{G}$ allele conferred significant increase of IL17 in patients as compared to corresponding controls. Furthermore,patients with GG genotype had the highest serum IL17 levels, followed by AG then AA genotypes. However, such differences were statistically significant onlyin between GG and AA patients.On the other hand, serum IL17 showed non-significant differences between the three genotypes in the control group. In line with these data,Leipe and colleagues, 2014demonstrated that presence of even one $G$ allele was associated with significantly higher frequency of Th 17 and IL17 production in RA patients. Furthermore, the present studydetected significant positive correlations between serum IL17 and DAS28 score in patients carrying AG and GG genotypes. However, only GG carriers showeda positive correlation with statistical significance between serum IL17 and Larsen scale.

Our results highlight the poor effect of ILARG allele on RA progression, a process in which IL-17 seems to be a crucial player.Interestingly, IL4 has been shown todecrease autoimmune inflammation, bone and joint destruction not only through above mentioned mechanisms but also by suppression of Th17/IL17 axis and effects (Cooney et al., 2011; Guenova et al., 2015; Leipe et al., 2014 and Wallis et al., 2011).

The current findings might be explained by the reduced ability of IL4 to suppress Th17 cells in carriers of G allele. Amino acid substitution due to rs1805010 GG genotype, reduces STAT6 activation, hence weakens the downstream signals through IL4R. Thus, production of IL4 is significantly diminished and TH17/IL17 suppression is diminished as well, in such patients(Cooney et al., 2011; Guenova et al., 2015; Leipe et al., 2014 and Wallis et al., 2011).

Finally, there were non-significant differences in serum levels of IL17 between patients on different treatment regimens in all three genotypes. In this regard, the present study was limited because all included patients were using conventional DMARDs due to very high cost of other biologic drugs.

CONCLUSION : In conclusion,IL17 may play a role in progression of RA disease.However, clinical effects of IL17 become more evident due to loss of suppression by IL4 in patients with hypofunctionalIL4R of GG genotype. Determining IL4Rrs 1805010 genetic variants, may allow early identification of those at risk of high disease activityfor special therapeutic approachto reduce morbidity as possible. To establish the benefit of such patients from treatment depending on anti- IL17 rather than IL4 mechanisms, further longitudinal cohort studies are needed,with a larger sample size focusing on new biologic treatment strategies and their outcome. 


\section{REFERENCES}

Al-Saadany H.M., Hussein M.S., Gaber R.A., Zaytoun H.A. (2016): Th-17 cells and serum IL-17 in rheumatoid arthritis patients: Correlation with disease activity and severity. The Egyptian Rheumatologist 38:1-7

Aletaha D., Nell V.P., Stamm T., Uffmann M., Pflugbeil S., Machold K., Smolen J.S. (2005): Acute phase reactants add little to composite disease activity indices for rheumatoid arthritis: validation of a clinical activity score. Arthritis Res Ther 7:R796-806

Aletaha D., Neogi T., Silman A.J., Funovits J., Felson D.T., Bingham C.O., 3rd, Birnbaum N.S., Burmester G.R., Bykerk V.P., Cohen M.D., Combe B., Costenbader K.H., Dougados M., Emery P., Ferraccioli G., Hazes J.M., Hobbs K., Huizinga T.W., Kavanaugh A., Kay J., Kvien T.K., Laing T., Mease P., Menard H.A., Moreland L.W., Naden R.L., Pincus T., Smolen J.S., Stanislawska-Biernat E., Symmons D., Tak P.P., Upchurch K.S., Vencovsky J., Wolfe F., Hawker G. (2010): 2010 Rheumatoid arthritis classification criteria: an American College of Rheumatology/European League Against Rheumatism collaborative initiative. Arthritis Rheum 62:2569-2581

Astry B., Harberts E., Moudgil K.D. (2011): A Cytokine-Centric View of the Pathogenesis and Treatment of Autoimmune Arthritis. Journal of Interferon \& Cytokine Research 31:927-940

Boniface K., Blumenschein W.M., Brovont-Porth K., McGeachy M.J., Basham B., Desai B., Pierce R., McClanahan T.K., Sadekova S., de Waal Malefyt R. (2010): Human Th17 cells comprise heterogeneous subsets including IFN-gamma-producing cells with distinct properties from the Th1 lineage. J Immunol 185:679-687

Burgos P.I., Causey Z.L., Tamhane A., Kelley J.M., Brown E.E., Hughes L.B., Danila M.I., van Everdingen A., Conn D.L., Jonas B.L., Callahan L.F., Smith E.A., Brasington R.D., Moreland L.W., van der Heijde D.M., Alarcón G.S., Bridges S.L. (2010): Association of IL4R single-nucleotide polymorphisms with rheumatoid nodules in African Americans with rheumatoid arthritis. Arthritis Research \& Therapy 12:R75-R75

Conti L., De Palma R., Rolla S., Boselli D., Rodolico G., Kaur S., Silvennoinen O., Niccolai E., Amedei A., Ivaldi F., Clerico M., Contessa G., Uccelli A., Durelli L., Novelli F. (2012): Th17 Cells in Multiple Sclerosis Express Higher Levels of JAK2, Which Increases Their Surface Expression of IFN- $\gamma$ R2. The Journal of Immunology 188:1011-1018

Cooney L.A., Towery K., Endres J., Fox D.A. (2011): Sensitivity and Resistance to Regulation by IL-4 during Th17 Maturation. The Journal of Immunology 187:4440-4450 
Dixon J., Bird H., Sitton N., Pickup M., Wright V. (1984): C-reactive protein in the serial assessment of disease activity in rheumatoid arthritis. Scand J Rheumatol 13:39-44

Dorner R., Alexander R., Moore T. (1987): Rheumatoid factors. Clin Chim Acta 167:1-21

Edavalath S., Singh A., Soni N., Mohindra N., Kumar S., Misra R. (2016): Peripheral blood T helper type 17 frequency shows an inverse correlation with disease activity and magnetic resonance imaging-based osteitis and erosions in disease-modifying anti-rheumatic drug- and steroid-naive established rheumatoid arthritis. Clinical \& Experimental Immunology 186:313-320

Guenova E., Skabytska Y., Hoetzenecker W., Weindl G., Sauer K., Tham M., Kim K.W., Park J.H., Seo J.H., Ignatova D., Cozzio A., Levesque M.P., Volz T., Koberle M., Kaesler S., Thomas P., Mailhammer R., Ghoreschi K., Schakel K., Amarov B., Eichner M., Schaller M., Clark R.A., Rocken M., Biedermann T. (2015): IL-4 abrogates T(H)17 cell-mediated inflammation by selective silencing of IL-23 in antigen-presenting cells. Proc Natl Acad Sci U S A 112:2163-2168

Harrington L.E., Hatton R.D., Mangan P.R., Turner H., Murphy T.L., Murphy K.M., Weaver C.T. (2005): Interleukin 17-producing CD4+ effector $\mathrm{T}$ cells develop via a lineage distinct from the T helper type 1 and 2 lineages. Nat Immunol 6:1123-1132

Hussein Y., El-Tarhouny S., Mohamed R., Pasha H., Abul-Saoud A. (2012): Association of interleukin-4 receptor gene polymorphisms with rheumatoid arthritis in Egyptian female patients. Joint Bone Spine 79:38-42

Krabben A., Wilson A.G., de Rooy D.P.C., Zhernakova A., Brouwer E., Lindqvist E., Saxne T., Stoeken G., van Nies J.A.B., Knevel R., Huizinga T.W.J., Toes R., Gregersen P.K., van der Helm-van Mil A.H.M. (2013): Brief Report: Association of Genetic Variants in the IL4 and IL4R Genes With the Severity of Joint Damage in Rheumatoid Arthritis: A Study in Seven Cohorts. Arthritis \& Rheumatism 65:3051-3057

Kugyelka R., Kohl Z., Olasz K., Mikecz K., Rauch T.A., Glant T.T., Boldizsar F. (2016): Enigma of IL-17 and Th17 Cells in Rheumatoid Arthritis and in Autoimmune Animal Models of Arthritis. Mediators of Inflammation 2016:11

Larsen A. (1995): How to apply Larsen score in evaluating radiographs of rheumatoid arthritis in long-term studies. The Journal of rheumatology 22:1974-1975

Leipe J., Grunke M., Dechant C., Reindl C., Kerzendorf U., Schulze-Koops H., Skapenko A. (2010): Role of Th17 cells in human autoimmune arthritis. Arthritis Rheum 62:2876-2885 
Leipe J., Schramm M.A., Prots I., Schulze-Koops H., Skapenko A. (2014): Increased Th17 Cell Frequency and Poor Clinical Outcome in Rheumatoid Arthritis Are Associated With a Genetic Variant in the IL4R Gene, rs1805010. Arthritis \& Rheumatology 66:1165-1175

Mohammed F.Z., Mostafa A.A., and Bassiony E.F.(2015): Interleukin-4 (IL4) and Interleukin-4 receptor alpha chain (IL-4R $\alpha$ ) gene polymorphisms in Egyptian Rheumatoid arthritis patients. Egy.J. Pure \& Appl. Sci. 53:53-61.

Noack M., Ndongo-Thiam N., Miossec P. (2016): Interaction among activated lymphocytes and mesenchymal cells through podoplanin is critical for a high IL-17 secretion. Arthritis Research \& Therapy 18:148

Park H., Li Z., Yang X.O., Chang S.H., Nurieva R., Wang Y.H., Wang Y., Hood L., Zhu Z., Tian Q., Dong C. (2005): A distinct lineage of CD4 T cells regulates tissue inflammation by producing interleukin 17. Nat Immunol 6:1133-1141

Pavlovic V., Dimic A., Milenkovic S., Krtinic D. (2014): Serum levels of IL17, IL-4, and INF $\gamma$ in Serbian patients with early rheumatoid arthritis. Journal of Research in Medical Sciences : The Official Journal of Isfahan University of Medical Sciences 19:18-22

Prots I., Skapenko A., Wendler J., Mattyasovszky S., Yone C.L., Spriewald B., Burkhardt H., Rau R., Kalden J.R., Lipsky P.E., Schulze-Koops H. (2006): Association of the IL4R single-nucleotide polymorphism I50V with rapidly erosive rheumatoid arthritis. Arthritis Rheum 54:1491-1500

Roeleveld D.M., Koenders M.I. (2015): The role of the Th17 cytokines IL17 and IL-22 in Rheumatoid Arthritis pathogenesis and developments in cytokine immunotherapy. Cytokine 74:101-107

van Gaalen F.A., Visser H., Huizinga T.W.J. (2005): A comparison of the diagnostic accuracy and prognostic value of the first and second anti-cyclic citrullinated peptides (CCP1 and CCP2) autoantibody tests for rheumatoid arthritis. Annals of the Rheumatic Diseases 64:1510-1512

Wallis S.K., Cooney L.A., Endres J.L., Lee M.J., Ryu J., Somers E.C., Fox D.A. (2011): A polymorphism in the interleukin-4 receptor affects the ability of interleukin-4 to regulate Th17 cells: a possible immunoregulatory mechanism for genetic control of the severity of rheumatoid arthritis. Arthritis Res Ther 13:R15 


\section{الملخص العربي}

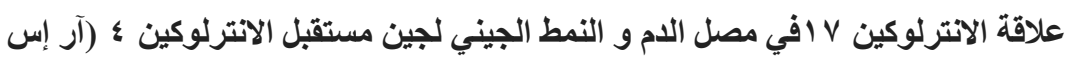

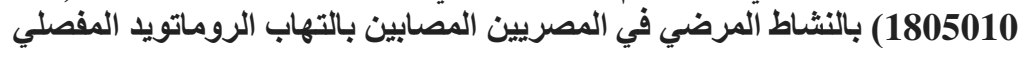

يتميز التهاب الروماتو يدالمفصليبوجود حالة من عدم التوازن النسبي بين السيتوكينات المؤيدة

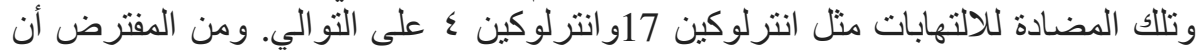

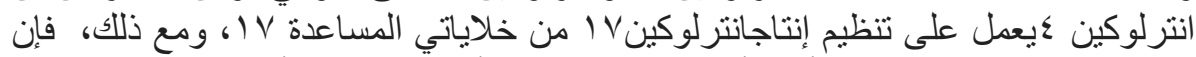

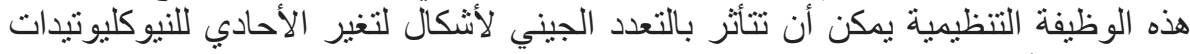

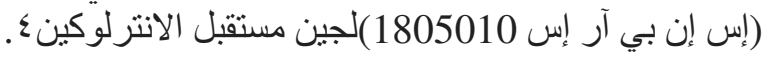

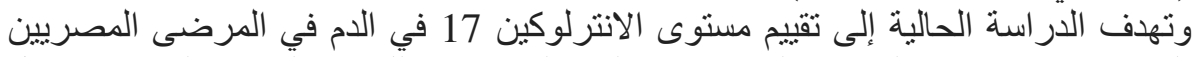

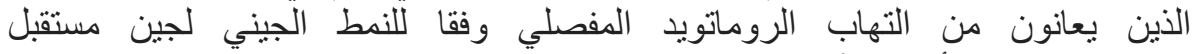

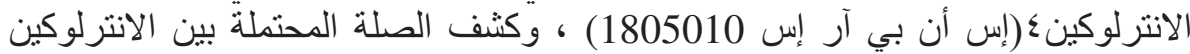

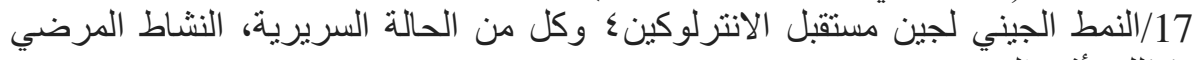

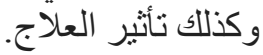

تم قياس مستوى الانترلوكين Vافي مصل الدم بواسطة الإليزا، في حين استخدمت تقنية

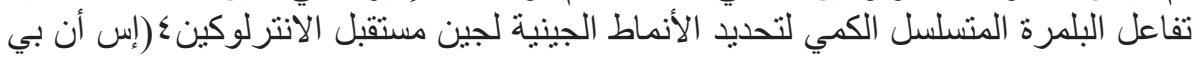

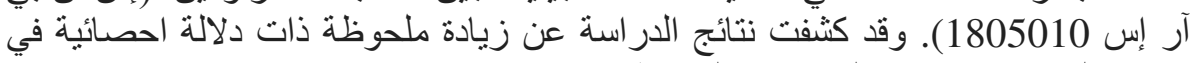
عينات المرضى مقارنة بالمجمو عة الضابطة.

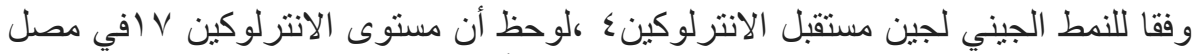

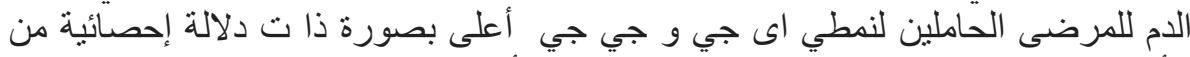

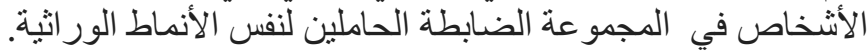

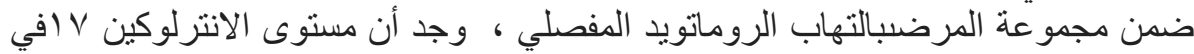

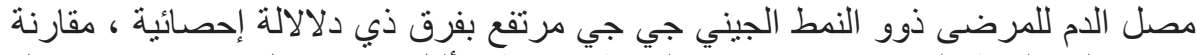

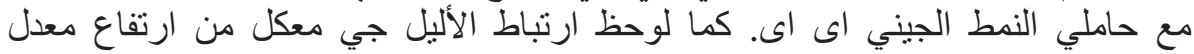

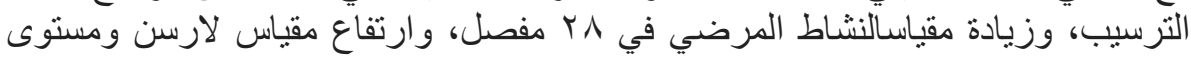

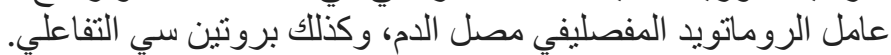

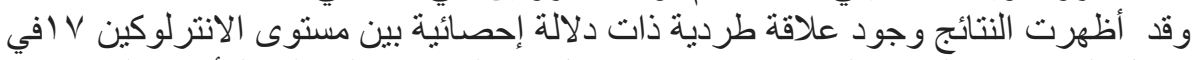

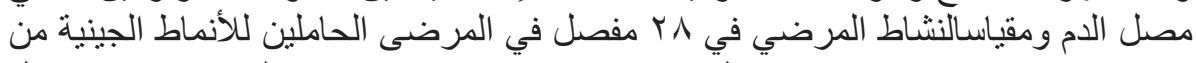

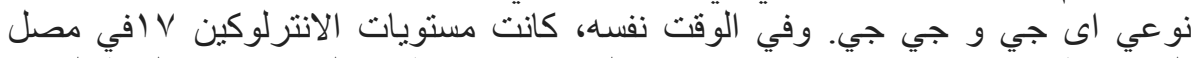

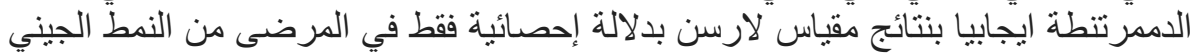

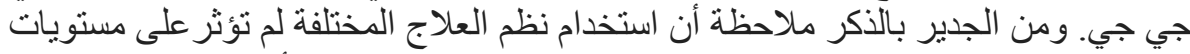

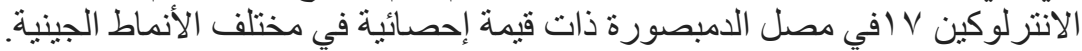

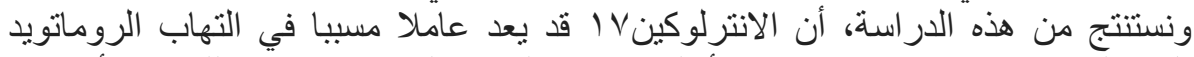

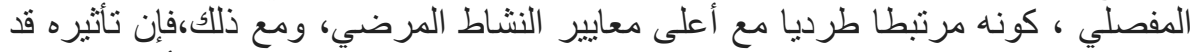

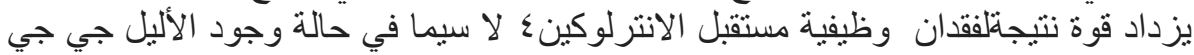

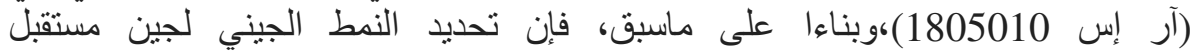
الانترلوكينء (آر إس 1805010)قد يكون واعدا لتحديد المرضى الأكثر عرضة للحالات المرضية الأسوأ. 